\title{
Dioxygen Activation at Non-Heme Diiron Centers: Characterization of Intermediates in a Mutant Form of Toluene/o- Xylene Monooxygenase Hydroxylase
}

\author{
Leslie J. Murray ${ }^{1}$, Ricardo García-Serres ${ }^{2}$, Sunil Naik ${ }^{2}$, Boi Hanh Huynh ${ }^{2,{ }^{*}}$, and Stephen J. \\ Lippard ${ }^{1, *}$ \\ 1Department of Chemistry, Massachusetts Institute of Technology, Cambridge, Massachusetts 02139 \\ 2Department of Physics, Emory University, Atlanta, Georgia 30322
}

Enzymes in the non-heme diiron super-family perform key biological functions ranging from radical generation for DNA biosynthesis to regio- and stereo-selective oxidation of hydrocarbons at structurally similar active sites. ${ }^{1}$ The features that determine the outcome of $\mathrm{O}_{2}$ activation at these sites are unclear and are currently of great interest.

In the catalytic cycles of these enzymes, a diiron(II) center reacts with $\mathrm{O}_{2}$ to generate reactive intermediates that have thus far been observed in only a few cases. ${ }^{2,3}$ Among members of the sub-family of bacterial multi-component monooxygenase (BMM) enzymes, ${ }^{4}$ soluble methane monooxygenase is the only one for which intermediates have been observed. In this system, the reduced hydroxylase component, $\mathrm{MMOH}$, reacts with $\mathrm{O}_{2}$ to generate spectroscopically characterized diiron(III) and diiron(IV) intermediates. ${ }^{3 a, b}$ Both of these species can oxidize hydrocarbons, ${ }^{3}$ which can enter the active site of $\mathrm{MMOH}$ via a string of hydrophobic pockets. ${ }^{5}$ In contrast, a large substrate-access channel is present in toluene/o-xylene monooxygenase hydroxylase (ToMOH), affording more exposed diiron sites. ${ }^{6} \mathrm{We}$ postulated that buffer components might quench the reactive intermediates in $\mathrm{ToMOH}$ and that mutations to block access to the diiron centers would facilitate the observation of intermediates. Following this strategy, we generated an I100W mutant in the $\alpha$-subunit of the ToMOH by site-directed mutagenesis and discovered an oxygenated diiron intermediate that oxidizes the newly supplied W100 residue.

The reaction of the chemically-reduced diiron(II) form of I100W ToMOH in the presence of the coupling protein, ToMOD, with $\mathrm{O}_{2}$-saturated buffer was monitored by stopped-flow UV/ visible spectroscopy. A transient species with an absorption band centered at $500 \mathrm{~nm}$ appeared with formation and decay rate constants $k_{\text {form }}=0.804 \pm 0.001 \mathrm{~s}^{-1}$ and $k_{\text {decay }}=0.054 \pm 0.002$ $\mathrm{s}^{-1}$ and an extinction coefficient, $\varepsilon_{500}$, of $1.5 \pm 0.2 \times 10^{3} \mathrm{M}^{-1} \mathrm{~cm}^{-1}$ (Figure S1). Based on these optical properties we tentatively assigned this species as a neutral tryptophan radical, $\mathrm{W}^{\bullet} .7$

To investigate further the reaction of I100W ToMOH with $\mathrm{O}_{2}$, rapid-freeze quench (RFQ) samples were prepared at various aging times and characterized by EPR and Mössbauer spectroscopy. A transient $g=2.00$ EPR signal with fine structure (Figure 1) was observed, as expected for a $\mathrm{W}^{\bullet}$ species. The intensity of this signal maximized at $\sim 3.5 \mathrm{~s}$, consistent with the kinetics of formation of the putative $\mathrm{W}^{\bullet}$ radical from the UV/visible stopped-flow study. The EPR signal is easily saturated at $10 \mathrm{~K}$ and can be detected up to $50 \mathrm{~K}$ without any broadening, properties typical of an organic radical. When ${ }^{57} \mathrm{Fe}$-enriched I100W was used in the reaction,

lippard@mit.edu and vhuynh@physics.emory.edu. 
however, hyperfine broadening was observed (Figure 1). This result unambiguously establishes that the diiron cluster contributes to this EPR signal. The observed hyperfine broadening is similar to that observed for the $g=2.00 \mathrm{EPR}$ signals of the spin-coupled diiron (III,IV) $\mathbf{X}-\mathrm{WH}^{+\bullet}$ in the ribonucleotide reductase R2 subunit (R2) ${ }^{2 \mathrm{~g}}$ and of $\mathbf{X}-\mathrm{Y}^{\bullet}$ in the R2$\mathrm{W} 48 \mathrm{~F}$ variant. ${ }^{2 \mathrm{~h}}$ The optical absorption and EPR spectral data therefore suggest a spin-coupled intermediate comprising $\mathrm{W}^{\bullet}$ and a paramagnetic diiron cluster. Mössbauer data (Figure 2) confirmed the spin-coupled nature of this intermediate and revealed the oxidation state of the paramagnetic diiron center to be mixed-valent diiron(III,IV).

Figure 2B displays the 4.2-K Mössbauer spectrum of the $3.5 \mathrm{~s}$ RFQ sample recorded with a 50-mT magnetic field applied parallel to the $\gamma$-beam. A paramagnetic spectral component with features (arrows) similar to the diiron(III,IV) intermediate, $\mathbf{X}$, in $\mathrm{R} 2{ }^{2 \mathrm{~g}}, \mathrm{~h}$ was observed. Analysis of the spectrum indicates that this component accounts for $15 \pm 2 \%$ of the total $\mathrm{Fe}$ absorption. The spectrum of this sample recorded with a strong applied field of $8 \mathrm{~T}$ (Figure 2C) showed a two-fold increase in the intensity of the paramagnetic component to $30 \pm 3 \%$ of total Fe absorption. This field-dependent increase of the paramagnetic absorption indicates that the $S=1 / 2$ diiron(III,IV) cluster is weakly spin-coupled to a nearby $S=1 / 2$ paramagnet. ${ }^{2 \mathrm{~h}}$ For a weakly-coupled system $\left(J<1 \mathrm{~cm}^{-1}\right)$ in a weak applied field of $50 \mathrm{mT}$, the energy separations of the four electronic levels are small, whereas in a strong applied field of $8 \mathrm{~T}$, the Zeeman interaction increases the energy separations between these levels. At $4.2 \mathrm{~K}$ and $50 \mathrm{mT}$, all four levels are nearly equally populated and the spectrum contains two equal-intensity components: a paramagnetic component (two $M_{\mathrm{S}}= \pm 1$ sublevels of the triplet state) superposed on a "diamagnetic" component (the singlet state and the $M_{\mathrm{S}}=0$ sublevel of the triplet state). In contrast, at $4.2 \mathrm{~K}$ and $8 \mathrm{~T}$, only the lowest $M_{\mathrm{S}}=-1$ sublevel is populated and the "diamagnetic" component disappears, doubling the intensity of the paramagnetic component. $2 \mathrm{~h}$ We compared a simulated spectrum of the $\mathrm{X}-\mathrm{Y}^{*}$ species in R2-W48F (Figure 2) to the spectrum of the $3.5 \mathrm{~s}$ sample and the agreement is remarkable and consistent with our assignment. The observed discrepancy in the central region of the spectrum indicates the presence of another intermediate (vide infra) and a diiron(III) product; in addition, the Mössbauer parameters for the I100W diiron(III,IV) may be slightly different than those of $\mathbf{X}$ in $\mathrm{R} 2-\mathrm{W} 48 \mathrm{~F}$.

Time-dependent EPR experiments indicate that the diiron(II) $g=16$ signal decays more rapidly $\left(\sim 60 \mathrm{~s}^{-1}\right)$ than the formation rate of the diiron(III,IV)-W ${ }^{\bullet} g=2$ signal (data not shown). An EPR-silent precursor to the diiron(III,IV)-W ${ }^{\bullet}$ species therefore must exist, the concentration of which would maximize at a reaction time of $\sim 100 \mathrm{~ms}$. Consistent with this conclusion, the Mössbauer spectrum of a sample quenched at $70 \mathrm{~ms}$ (Figure 2A) shows a sharp quadrupole doublet accounting for approximately $30 \%$ of the total Fe absorption, as well as the broad quadrupole doublet of the initial diiron(II) protein. The parameters of the sharp quadrupole doublet $\left(\delta=0.54 \pm 0.02 \mathrm{~mm} / \mathrm{s}\right.$ and $\left.\Delta E_{Q}=0.66 \pm 0.03 \mathrm{~mm} / \mathrm{s}\right)$ are typical of high-spin Fe ${ }^{\text {III }}$ species. Spectra recorded with strong applied fields and the EPR data indicate that this doublet arises from an antiferromagnetically coupled diiron(III) cluster. In the $3.5 \mathrm{~s}$ sample, the intensity of this doublet is diminished substantially and accounts for less than $7 \%$ of the $\mathrm{Fe}$ absorption, establishing that this diiron(III) intermediate decays during formation of the spincoupled diiron(III,IV)-W* species. This diiron(III) species is the first observable intermediate after reaction with $\mathrm{O}_{2}$ and, based on work with other non-heme diiron proteins, ${ }^{2}$ we tentatively assign this species as a peroxodiiron(III) unit. The Mössbauer parameters for this species in I100W ToMOH, however, differ from those reported for the peroxodiiron(III) intermediates in other carboxylate-bridged diiron proteins, for which $\delta>0.6 \mathrm{~mm} / \mathrm{s}$ and $\Delta E_{Q}>1.00 \mathrm{~mm} / \mathrm{s} .{ }^{8}$ Furthermore, the peroxo species in these proteins exhibit optical absorptions with $\lambda_{\text {max }}$ greater than $650 \mathrm{~nm}^{2 \mathrm{~d}-\mathrm{g}}$ and no such features are observed for I100W ToMOH. Peroxodiiron(III) synthetic complexes with a planar $\mu$-1,2-peroxo coordination mode and a second bridging ligand ${ }^{9}$ have $\delta$ and $\Delta E_{Q}$ values similar to those reported here for the putative peroxodiiron(III) 
intermediate. The mechanism by which the diiron(III,IV) center and $\mathrm{W}^{*}$ radical form in I100W ToMOH may be similar to that proposed for the generation of $\mathbf{X}$ and $\mathrm{Y}^{*}$ in R2. ${ }^{2 h}$ Preliminary evidence indicates that decay of the diiron(III,IV) and $\mathrm{W}^{*}$ species may proceed via hydroxylation of W100 (unpublished results).

The detection of an early transient for I100W ToMOH with Mössbauer parameters atypical of those for peroxodiiron(III) species and no obvious visible absorption band led us to examine the time-dependent Mössbauer spectra of the reaction of the wild-type enzyme with $\mathrm{O}_{2}$. The results indicate unambiguously the accumulation of a transient with a spectrum identical to that observed for the diiron(III) intermediate in the I100W ToMOH variant (unpublished results). Detailed spectroscopic investigations of this intermediate are in progress. Peroxo $3 \mathrm{c}$, 10 and hydroperoxo ${ }^{11}$ species are proposed to be reactive intermediates in metalloenzymes, and this putative peroxo adduct may be the active oxidant for aromatic hydroxylation in the ToMO systems.

\section{Supplementary Material}

Refer to Web version on PubMed Central for supplementary material.

\section{Acknowledgements}

This work was supported by NIH Grants GM32134 (to SJL) and GM 47295 (to BHH). LJM was supported in part by a fellowship from the Martin Society.

\section{References}

1. Kurtz DM Jr. J Biol Inorg Chem 1997;2:159-167.

2. (a) Lee SK, Fox BG, Froland WA, Lipscomb JD, Münck E. J Am Chem Soc 1993;115:6450-6451. (b) Liu KE, Wang D, Huynh BH, Edmonsdon DE, Salifoglou A, Lippard SJ. J Am Chem Soc 1994;116:7465-7466. (c) Burdi D, Willems JP, Riggs-Gelasco P, Antholine WE, Stubbe J, Hoffman BM. J Am Chem Soc 1998;120:12910-12919. (d) Moënne-Loccoz P, Baldwin J, Ley BA, Loehr TM, Bollinger JM Jr. Biochemistry 1998;37:14659-14663. [PubMed: 9778340] (e) Pereira AS, Small W, Krebs C, Tavares P, Edmondson DE, Theil EC, Huynh BH. Biochemistry 1998;37:9871-9876. [PubMed: 9665690] (f) Broadwater JA, Ai J, Loehr TM, Sanders-Loehr J, Fox BG. Biochemistry 1998;37:14664-14671. [PubMed: 9778341] (g) Baldwin J, Krebs C, Ley BA, Edmondson DE, Huynh BH, Bollinger JM Jr. J Am Chem Soc 2000;122:12195-12206. (h) Krebs C, Chen S, Baldwin J, Ley BA, Patel U, Edmonsdon DE, Huynh BH, Bollinger JM Jr. J Am Chem Soc 2000;122:12207-12219.

3. (a) Nesheim JC, Lipscomb JD. Biochemistry 1996;35:10240-10247. [PubMed: 8756490] (b) Valentine AM, Stahl SS, Lippard SJ. J Am Chem Soc 1999;121:3876-3887. (c) Beauvais LG, Lippard SJ. J Am Chem Soc 2005;127:7370-7378. [PubMed: 15898785]

4. Leahy JG, Batchelor PJ, Morcomb SM. FEMS Micro Rev 2003;27:449-479.

5. (a) Rosenzweig AC, Brandstetter H, Whittington DA, Nordlund P, Lippard SJ, Frederick CA. Proteins 1998;29:141-152. [PubMed: 9329079] (b) Whittington DA, Rosenzweig AC, Frederick CA, Lippard SJ. Biochemistry 2001;40:3476-3482. [PubMed: 11297413]

6. Sazinsky MH, Bard J, Di Donato A, Lippard SJ. J Biol Chem 2004;279:30600-30610. [PubMed: 15096510]

7. Aubert C, Vos MH, Mathis P, Eker APM, Brettel K. Nature 2000;405:586-590. [PubMed: 10850720]

8. Merkx M, Kopp DA, Sazinsky MH, Blazyk JL, Müller J, Lippard SJ. Angew Chem Int Ed 2001;40:2782-2807.

9. (a) Menage S, Brennan BA, Juarez-Garcia C, Münck E, Que L Jr. J Am Chem Soc 1990;112:64236425. (b) Dong Y, Yan S, Young VG Jr, Que L Jr. Angew Chem Int Ed 1996;35:618-620. (c) Zhang X, Furutachi H, Fujinami S, Nagatomo S, Maeda Y, Watanabe Y, Kitagawa T, Suzuki M. J Am Chem Soc 2004;127:826-827. [PubMed: 15656607]

10. (a) Decker H, Dillinger R, Tuczek F. Angew Chem Int Ed 2000;39:1591-1594. (b) Baldwin J, Voegtli WC, Khidekel N, Moënne-Loccoz P, Krebs C, Pereira AS, Ley BA, Huynh BH, Loehr TM, Riggs- 
Gelasco PJ, Rosenzweig AC, Bollinger JM Jr. J Am Chem Soc 2001;123:7017-7030. [PubMed: 11459480] (c) Yamazaki, Si; Morioka, C.; Itoh, S. Biochemistry 2004;43:11546-11553. [PubMed: 15350140]

11. (a) Vatsis KP, Coon MJ. Arch Biochem Biophys 2002;397:119-129. [PubMed: 11747318] (b) Jin S, Bryson TA, Dawson JH. J Biol Inorg Chem 2004;9:644-653. [PubMed: 15365901] (c) Nam W, Ryu YO, Song WJ. J Biol Inorg Chem 2004;9:654-660. [PubMed: 15365902] 


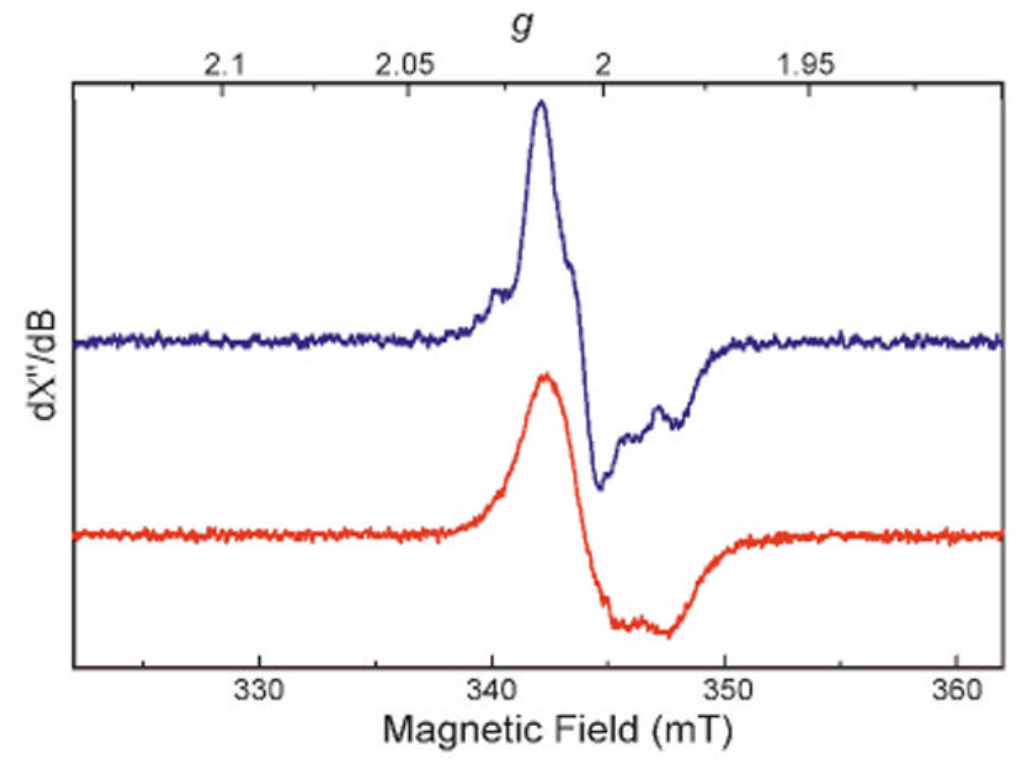

Figure 1.

EPR spectra of the diiron(III,IV)-W $\mathrm{W}^{\bullet}$ intermediate generated in the reaction of reduced ToMOH-I100W with $\mathrm{O}_{2}$. The reaction was quenched at $4 \mathrm{~s}$ using natural-abundant diiron(II) protein (blue) or at $3.5 \mathrm{~s}$ using ${ }^{57} \mathrm{Fe}$-enriched protein (red). 


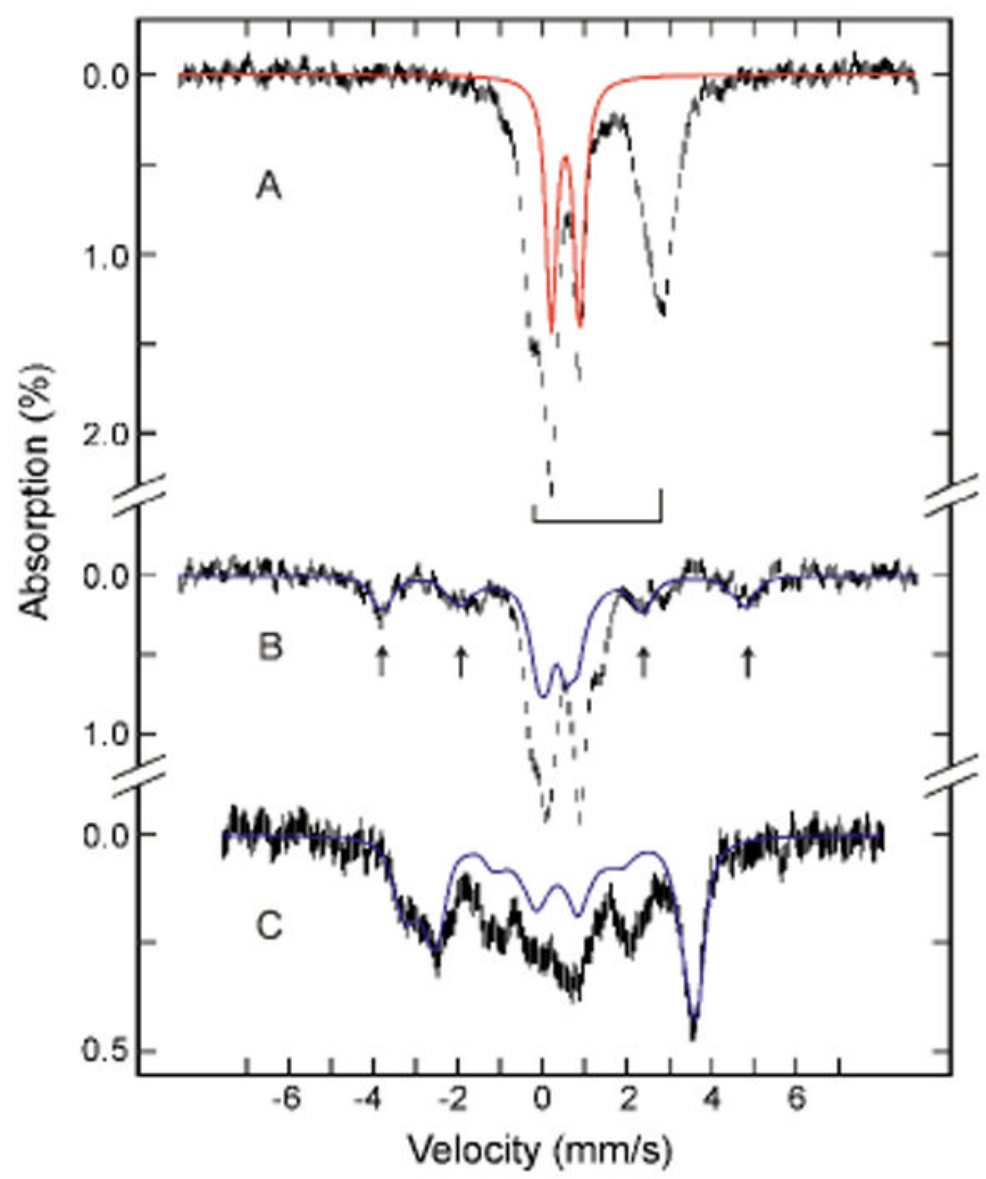

Figure 2.

Mössbauer spectra of samples freeze-quenched at $70 \mathrm{~ms}$ (A) and $3.5 \mathrm{~s}$ (B and C) in the reaction of diiron(II) I100W ToMOH with $\mathrm{O}_{2}$. The data were recorded at $4.2 \mathrm{~K}$ in a parallel applied field of $50 \mathrm{mT}$ (A and B) or $8 \mathrm{~T}(\mathrm{C})$. For the spectra in B and C, the diiron(II) contributions (50\% of the total Fe absorption) were removed from the raw data for clarity. Simulated spectra of the peroxo intermediate (A, red line) and of the $\mathrm{X}-\mathrm{Y}^{\bullet}$ species in $\mathrm{R} 2-\mathrm{W} 48 \mathrm{~F}$ (B and C, blue lines) are superimposed and scaled to $30 \%$ of the total absorption of that sample. The bracket (A) indicates the diiron(II) protein. Raw data are denoted as vertical bars. 